\title{
The role of hydrological model complexity and uncertainty in climate change impact assessment
}

\author{
R. Ludwig ${ }^{1}$, I. May ${ }^{1}$, R. Turcotte ${ }^{2}$, L. Vescovi ${ }^{3}$, M. Braun ${ }^{1}$, J.-F. Cyr ${ }^{2}$, L.-G. Fortin ${ }^{2}$, D. Chaumont ${ }^{3}$, S. Biner ${ }^{3}$, \\ I. Chartier ${ }^{3,4}$, D. Caya ${ }^{3}$, and W. Mauser ${ }^{1}$ \\ ${ }^{1}$ Department of Geography, University of Munich, Germany \\ ${ }^{2}$ Centre d'Expertise Hydrique du Québec, Québec, Canada \\ ${ }^{3}$ Consortium Ouranos, Montréal, Canada \\ ${ }^{4}$ Hydro Quebec, Montréal, Canada
}

Received: 19 January 2009 - Revised: 30 March 2008 - Accepted: 28 April 2009 - Published: 11 August 2009

\begin{abstract}
Little quantitative knowledge is as yet available about the role of hydrological model complexity for climate change impact assessment. This study investigates and compares the varieties of different model response of three hydrological models (PROMET, Hydrotel, HSAMI), each representing a different model complexity in terms of process description, parameter space and spatial and temporal scale. The study is performed in the Ammer watershed, a $709 \mathrm{~km}^{2}$ catchment in the Bavarian alpine forelands, Germany. All models are driven and validated by a 30 -year time-series (1971-2000) of observation data. It is expressed by objective functions, that all models, HSAMI and Hydrotel due to calibration, perform almost equally well for runoff simulation over the validation period. Some systematic deviances in the hydrographs and the spatial patterns of hydrologic variables are however quite distinct and thus further discussed.

Virtual future climate (2071-2100) is generated by the Canadian Regional Climate Model (vers 3.7.1), driven by the Coupled Global Climate Model (vers. 2) based on an A2 emission scenario (IPCC 2007). The hydrological model performance is evaluated by flow indicators, such as flood frequency, annual 7-day and 30-day low flow and maximum seasonal flows. The modified climatic boundary conditions cause dramatic deviances in hydrologic model response. HSAMI shows tremendous overestimation of evapotranspiration, while Hydrotel and PROMET behave in comparable range. Still, their significant differences, like spatially explicit patterns of summerly water shortage or spring flood intensity, highlight the necessity to extend and quantify
\end{abstract}

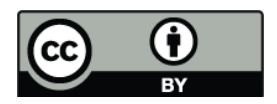

Correspondence to: R. Ludwig (r.ludwig@1mu.de) the uncertainty discussion in climate change impact analysis towards the remarkable effect of hydrological model complexity. It is obvious that for specific application purposes, water resources managers need to be made aware of this effect and have to take its implications into account for decision making. The paper concludes with an outlook and a proposal for future research necessities.

\section{Background and introduction}

Global climate change will impose remarkable regional alterations on landscape systems, regional water cycles in general and catchment hydrology in particular. It is understood that even the most sophisticated regional climate models, driven by GCMs (General Circulation Models), are not capable to fully project the exact future course of water related variables. While general trends are concurrently represented in most GCMs, large uncertainties still remain in the projected magnitude, variability and especially regional patterns. Still, these data are the best available source of information to develop adaptation strategies for water resources managers. They serve as driving inputs for subsequent hydrological models, transferring a future climate signal into hydrological quantities at the landscape or watershed scale.

Nowadays, operational organisations that are seeking for effective adaptation options have access to a large number of outputs from climate models that cover a wide spectrum of possible futures. The great uncertainties, that are inherent to these climate projections as well as to subsequent modelling tools (Minville et al., 2008; Khalili et al., 2006), are currently the limiting factor to put meaningful adaptation options into practice. New and concise concepts must be developed to

Published by Copernicus Publications on behalf of the European Geosciences Union. 
reduce these uncertainties and comprehensive tools must be provided to stakeholders to simplify and foster the process of reasoned decision making in watershed management under climate change conditions (Garrido and Dinar, 2009).

Water resources agencies and institutions usually employ hydrological models for specific operational purposes, such as flood forecasting or dam management (Turcotte et al., 2004). These models often follow rather simple concepts and are usually exposed to more or less sophisticated calibration procedures (Refsgard, 2001; Beven and Freer, 2001; Duan et al., 1993). While reliable and accurate results can be obtained under current state conditions, these models are seldom readily prepared for utilization in a climate change context, where the predictive power of such models becomes more and more important and raises the demand for processbased and spatially explicit model types. However, difficulties with these models include the high data demand, wide parameter space, complex process descriptions and complicated handling. In order for these institutions to develop sound adaptation strategies, a compromise must be found between the principles of operational model applicability and sufficient predictive power for climate change impact assessment. It must be understood that the level of complexity of a given hydrological model may limit its application to a certain set of problems, characterized by temporal and spatial scales or by predominant hydrological decision variables (for example stream flow at the watershed outlets or soil moisture at field scale), while other tasks may need more complex process descriptions.

While scientific expertise has been collected about hydrologic model uncertainty for short to medium range forecasts, e.g. in terms of hydrological model ensembles in the HEPEX experiment (Schaake et al., 2006) or the RAPHAEL project (Bacchi and Ranzi, 2003), little quantitative knowledge is as yet available about the role of hydrological model complexity for climate change impact assessment. The presented research investigates the varieties of different model response as a function of model complexity. It is performed in the Ammer watershed, a $709 \mathrm{~km}^{2}$ catchment in the Bavarian alpine forelands, Germany. It is thus not so much focused on revealing the projected climate change for this region (which is clearly not possible when being based on one single GCMRCM (Regional Climate Model) driver only), but is much more intended to demonstrate the level of uncertainty which is introduced, when hydrological models of different structure and complexity are driven by the same climatological boundary conditions. The aim is to define a suitable level of model complexity in terms of parameter space, spatial and temporal scale (Sivapalan, 2003), capable to provide the required advice for water managers (Brugnach et al., 2007; Olsson and Anderson, 2007).

The study was performed within the joint BavarianQuébec research project AQAGI (Adaptation et intercomparaison d'outils québecois et bavarois de gestion intégrée de bassins versants dans un contexte de changements cli-

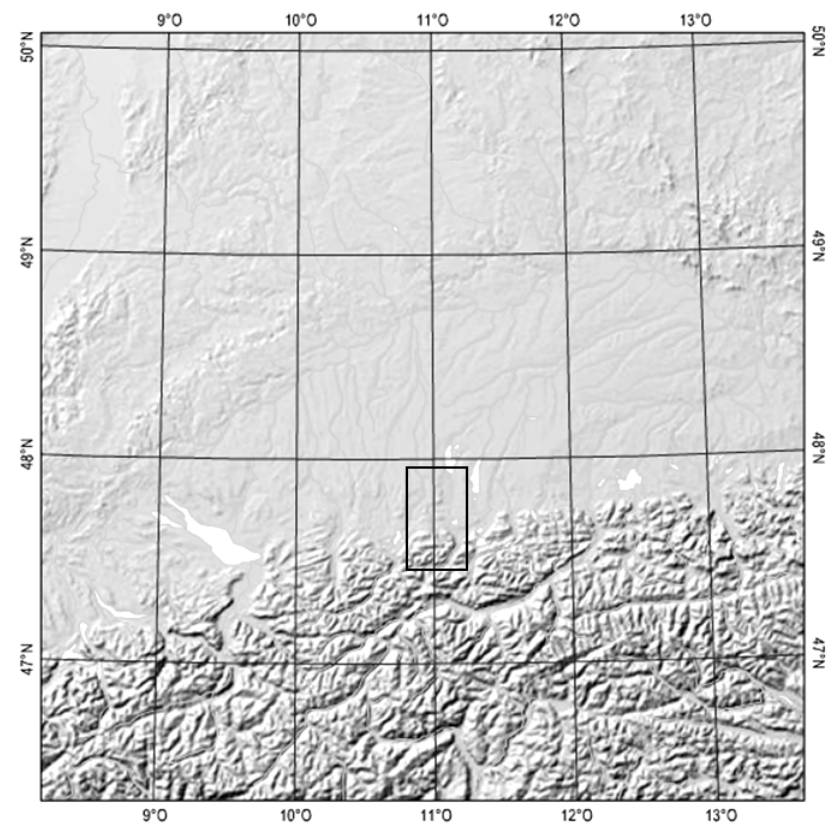

Fig. 1a. Location of the Ammer catchment in Southern Bavaria, Germany (taken from: Global Change Atlas Upper Danube (www. glowa-danube.de/atlas/atlas.php)).

matiques = Adaptation and comparison of a Quebecois and a Bavarian integrative water management tool in the context of climate change questions) between the Consortium Ouranos in Montréal, Canada and the Department of Geography at the University of Munich, Bavaria (Vescovi et al., 2009).

\section{Analysis and results}

As the study shall serve to better evaluate the required complexity of hydrological models applied in the context of climate change, the three applied hydrological models are each representing a different model complexity in terms of process description, parameter space and spatial and temporal scale: All models are driven and validated by a 30-year time series (1971-2000) of observation data. Additional comparative model runs were performed using different historic and future climate data from the Canadian Regional Climate Model (CRCM, vers. 3.7.1) (Plummer et al., 2006).

The study is performed in the Ammer watershed, a $709 \mathrm{~km}^{2}$ catchment in the Bavarian alpine forelands, Germany. The catchment area of the Ammer, located $50 \mathrm{~km}$ southwest of Munich, is dominated by agricultural use (see Fig. 1a and b). It ranges $50 \mathrm{~km}$ south to north from its spring in the steep Ammer Mountains to the gently rolling morainic topography at its mouth at Lake Ammer (Ludwig et al., 2003). The east - west extension of $30 \mathrm{~km}$ is limited by the catchments of the Loisach in the south- east and the Lech in the west. 

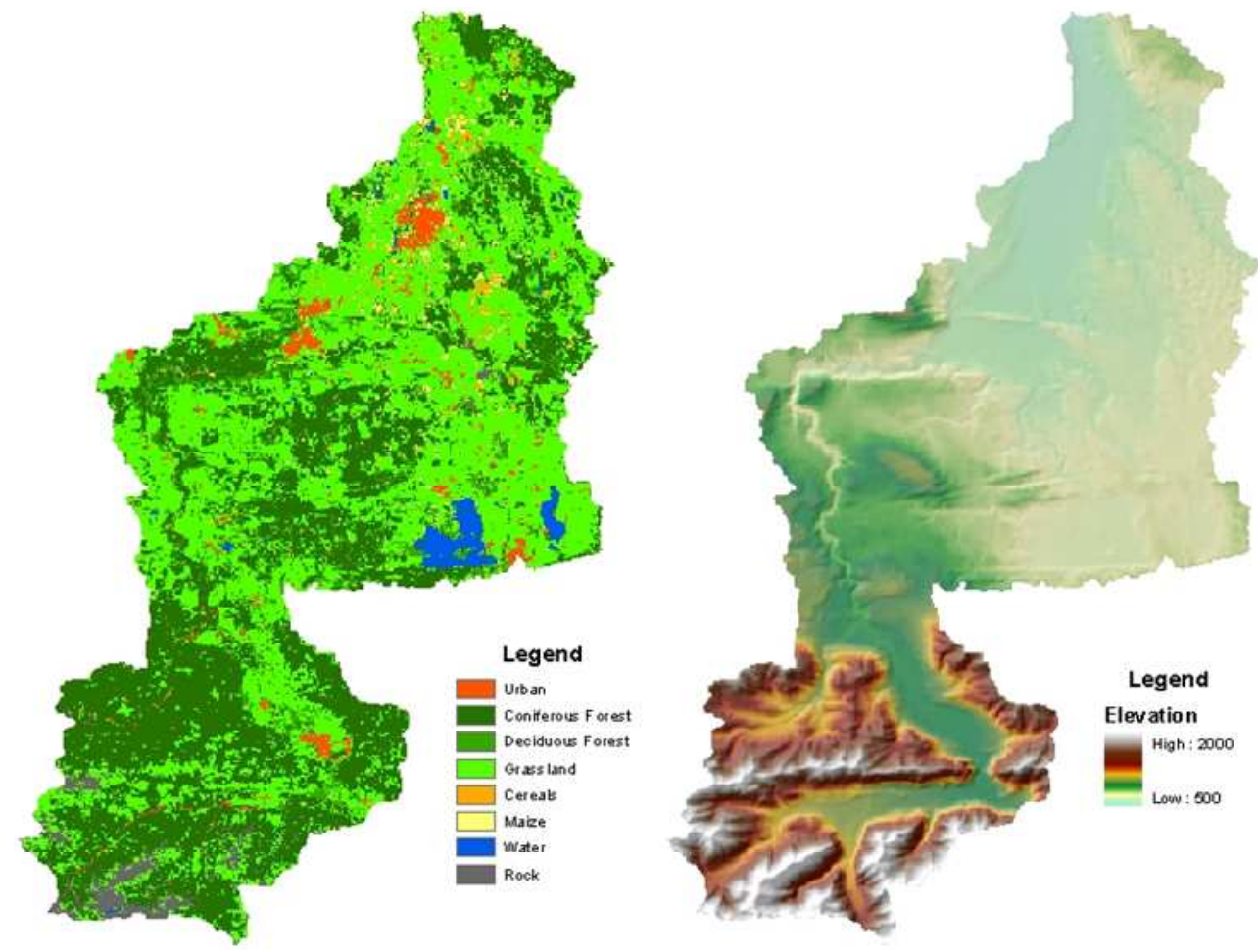

Fig. 1b. Ammer basin: Left: Land Use Cover based on a Landsat-TM-scene dating from June 19th 2000. Right: Digital Elevation Model, based on the DGM25 of the Bavarian Geodetic Survey.

\subsection{Hydrological models}

For the modelling process the following hydrological models are applied:

A) PROMET: The spatial distributed hydrological model PROMET (Processes of Radiation, Mass and Energy Transfer) simulates water balance components as well as river discharge based on a physical description on the land surface. It was specifically developed to study the impact of climate change on the water cycle of medium sized, complex watersheds influenced by different hydrologic regimes. PROMET is developed and tested at the LMU Munich within the integrative research project GLOWA-Danube (Ludwig and Mauser, 2000; Mauser and Ludwig, 2002; Ludwig et al., 2003) in collaboration with VISTA (Mauser and Bach, 2009). PROMET is spatially explicit in all process descriptions. In order to be most compatible with models from other disciplines (e.g. regional climate models, groundwater models) the spatial representation in PROMET is based on an isotropic grid. It follows the concept of avoiding calibration of model parameters against measured discharges. It thereby allows prognostic simulations for investigating the impact of climate change on the water cycle. The spatial parameterization of the land surface is provided using remote sensing data and GIS-methods.

B) HYDROTEL is a hydrological model developed by INRS-ETE (Institut $N$ ational de la Recherche $S$ cientifique) in
Quebec City, Canada, to simulate stream flow either within an operational forecasting framework or a study framework. It is a semi-distributed model operating at RHHUs (Turcotte et al., 2003), relative homogeneous hydrological units, on which the vertical water budgets are computed separately, so as to take into account the spatial variability of topography, land use, soil types and meteorological variables within a watershed. Its main objectives are to compute the stream flow for the concerned river and its major tributaries and to simulate the spatial distribution of hydrological variables (snow cover, soil moisture, etc.). It also uses the SCE-UA approach for calibration means.

C) HSAMI (Fortin, 2000) is a lumped bucket-type conceptual model, which has been developed at Hydro Quebec. It uses as input the basin average values of daily precipitation and minimum and maximum temperature to form snow cover and snow melt following a degree-day approach and to calculate evapotranspiration from empirical relationships (Frigon et al., 2002). Calibration of the model is performed and based on the Shuffled Complex Evolution-University of Arizona (SCE-UA).

A comparative description of all model types is given in Table 1.

In this study, PROMET and Hydrotel were operated in an hourly mode, whereas HSAMI calculated on a $24 \mathrm{~h}$ time increment. For the intercomparison, PROMET and Hydrotel results were averaged to daily means or sums respectively. 
Table 1. Major characteristics of the applied models.

\begin{tabular}{|c|c|c|c|}
\hline & PROMET & HYDROTEL & HSAMI \\
\hline Model type & $\begin{array}{l}\text { Mutliscale, raster-based dis- } \\
\text { tributed model }\end{array}$ & $\begin{array}{l}\text { Distributed model on small } \\
\text { sub-watershed }\end{array}$ & Lumped model \\
\hline Input variables & $\begin{array}{l}\mathrm{P}, \mathrm{T}, \mathrm{W}, \mathrm{R}, \mathrm{Rh} \text { (more if avail- } \\
\text { able) }\end{array}$ & $\begin{array}{l}\mathrm{P}, \mathrm{T} \text { (or more if available } \mathrm{W}, \mathrm{R}, \\
\mathrm{Rh} \text { ) }\end{array}$ & $\mathrm{P}, \mathrm{T}$ \\
\hline Time steps & $\begin{array}{l}1 \mathrm{~h}, 2 \mathrm{~h}, 3 \mathrm{~h}, 4 \mathrm{~h}, 6 \mathrm{~h}, 8 \mathrm{~h}, 12 \mathrm{~h} \\
\text { and } 24 \mathrm{~h}\end{array}$ & $\begin{array}{l}1 \mathrm{~h}, 2 \mathrm{~h}, 3 \mathrm{~h}, 4 \mathrm{~h}, 6 \mathrm{~h}, 8 \mathrm{~h}, 12 \mathrm{~h} \\
\text { and } 24 \mathrm{~h}\end{array}$ & 24 h only \\
\hline Output variables & $\begin{array}{l}\text { Streamflow at the watershed } \\
\text { outlet Spatially distributed } \\
\text { runoff, soil moisture, evapora- } \\
\text { tion, SWE, ... }\end{array}$ & $\begin{array}{l}\text { Streamflow at all the mod- } \\
\text { eled river reaches Spatially } \\
\text { distributed runoff, soil mois- } \\
\text { ture, SWE,... }\end{array}$ & $\begin{array}{l}\text { Streamflow at the watershed } \\
\text { outled }\end{array}$ \\
\hline Vertical budget & $\begin{array}{l}3 \text { layer soil water module } \\
\text { based on the Philip equa- } \\
\text { tion Layer properties parame- } \\
\text { terized by Brooks and Corey, } \\
\text { Brakensiek and Rawls Infiltra- } \\
\text { tion is based on soil hydraulic } \\
\text { conductivity and saturation of } \\
\text { the subsurface layer }\end{array}$ & $\begin{array}{l}3 \text { layers that mimic subsurface, } \\
\text { vadose and saturated parts of } \\
\text { the soil Layer properties and } \\
\text { exchanges are linked to phys- } \\
\text { ically based features Infiltra- } \\
\text { tion is based on soil hydraulic } \\
\text { conductivity and saturation of } \\
\text { the subsurface layer }\end{array}$ & $\begin{array}{l}2 \text { reservoirs (vadose and satu- } \\
\text { rated) Infiltration account for } \\
\text { frozen soil and for a saturation } \\
\text { threshold in the vadose reser- } \\
\text { voir }\end{array}$ \\
\hline Flow calculation & Extended Muskingum-Cunge & $\begin{array}{l}1 \text { geomorphologic unit hydro- } \\
\text { graph } 1 \mathrm{~d} \text { hydraulic approach } \\
\text { in the river and lake network }\end{array}$ & $\begin{array}{l}3 \text { synthetic unit hydrographs } \\
\text { (surface, vadose, saturated) }\end{array}$ \\
\hline ET calculation & Penman-Monteith equation & $\begin{array}{l}\text { PET Empirical based on air } \\
\text { temperature (HQ approach) or } \\
\text { more complex approach if data } \\
\text { are available AET based on ac- } \\
\text { tual water content and vegeta- } \\
\text { tion roots depth }\end{array}$ & $\begin{array}{l}\text { PET Empirical based on air } \\
\text { temperature (HQ approach) } \\
\text { AET proportional to the level } \\
\text { of vadose reservoir }\end{array}$ \\
\hline Snow model & $\begin{array}{l}\text { Muli-layer energy balance ap- } \\
\text { proach }\end{array}$ & $\begin{array}{l}\text { Temperature driven approach } \\
\text { that includes main energy bud- } \\
\text { get concepts }\end{array}$ & $\begin{array}{l}\text { Temperature driven approach } \\
\text { that includes some energy bud- } \\
\text { get concepts }\end{array}$ \\
\hline Set-up and calibration & No calibration & 15 parameters with SCE-UA & 23 parameters with SCE-UA \\
\hline & & $\begin{array}{l}\text { Model installation and calibra- } \\
\text { tion take roughly } 2 \text { months }\end{array}$ & $\begin{array}{l}\text { Model installation and calibra- } \\
\text { tion can be done in } 1 \text { day }\end{array}$ \\
\hline Utilization & $\begin{array}{l}\text { Numerous applications in re- } \\
\text { search and development }\end{array}$ & $\begin{array}{l}\text { Operationally used at CEHQ } \\
\text { and in the way to be used at } \\
\text { HQ }\end{array}$ & $\begin{array}{l}\text { Operationally used at Hydro- } \\
\text { Quebec }\end{array}$ \\
\hline Main References & Mauser (2009) & Fortin et al. (2001) & Fortin (2000) \\
\hline
\end{tabular}

\subsection{Validation of hydrological models}

The validation of the hydrological models in use is based on a 30-year time series of hydrological and meteorological station observations (1971-2000) from 12 climate stations of the German Weather Service (see Fig. 2). It was found that by means of Nash-Sutcliffe efficiency (NSC) and $R^{2}$, all models perform comparably well when driven by observation data. This can be underlined by Table 2 , showing the objective function values for consecutive 5-year time slots of simulated versus measured daily runoff. Calibration of the models Hydrotel and HSAMI was performed for the 19952000 time slice, with 1971-1994 being the validation period. Figure 3 compares measured mean annual runoff $\left[\mathrm{m}^{3} / \mathrm{s}\right]$ over the 30 year period with the model results of PROMET, HYDROTEL and HSAMI. Both, gain and the coefficient of determination of the resulting regression function indicate an acceptable model performance.

However, a number of deviances, especially in terms of summerly runoff can be attributed to different interpolation schemes of gauged precipitation and the different process equations for evapotranspiration and snowmelt (see Fig. 2). Largest deviations are visible for the lumped HSAMI model, which does not account for spatial heterogeneities - a clear disadvantage, especially in areas with strong topographic and climatic gradients. 
Table 2. Nash-Sutcliffe efficiency for six consecutive 5-year time slots of simulated daily runoff (the period 1995-2000 was used for the calibration of Hydrotel and HSAMI (in italic)).

\begin{tabular}{lll}
\hline Time Period & Model & NSC \\
\hline $01.01 .1971-01.01 .1975$ & PROMET & 0,58 \\
& HYDROTEL & 0.67 \\
& HSAMI & 0.55 \\
$01.01 .1975-01.01 .1980$ & PROMET & 0.76 \\
& HYDROTEL & 0.66 \\
& HSAMI & 0.72 \\
$01.01 .1980-01.01 .1985$ & PROMET & 0.60 \\
& HYDROTEL & 0.64 \\
$01.01 .1985-01.01 .1990$ & HSAMI & 0.49 \\
& PROMET & 0,55 \\
& HYDROTEL & 0.73 \\
$01.01 .1990-01.01 .1995$ & PROMET & 0.52 \\
& HYDROTEL & 0,65 \\
& HSAMI & 0.46 \\
$01.01 .1995-01.01 .2000$ & PROMET & 0.74 \\
& HYDROTEL & 0.83 \\
& HSAMI & 0.73 \\
\hline
\end{tabular}

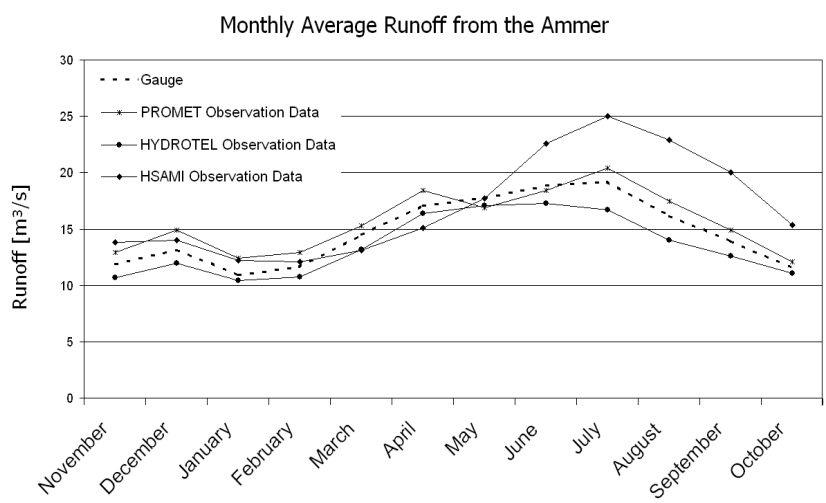

Fig. 2. Mean monthly runoff (1971-2000) in the Ammer catchment as simulated by PROMET, Hydrotel and HSAMI (driven by observed climate data).

\subsection{Water balance simulation using regional climate model data}

Comparative model runs were performed using different climate forcing for various time frames: observation data from the German Weather Service already mentioned in the chapter 2.2 "validation of hydrological models", historic climate data from the Canadian Regional Climate Model (CRCM, vers. 3.7.1) based on i) reanalysis data (ERA-40) and ii) driven by the Coupled Global Circulation Model (CGCM2 Past) and finally iii) a climate scenario based on an IPCC-A2 emission scenario (CGCM2 Future). It is taken into account that these driving inputs, also the ERA40 reanalysis often used for rainfall verification in spite of known deficiencies (Hagemann et al., 2005), are largely inadequate (Lucarini et al., 2007) for hydrological applications at the catchment scale. As expected, Table 3 and Fig. 4 highlight extreme deviations in the driving meteorological parameters and their consequences for all model results (Table 4). Please note the deviances between PROMET and Hydrotel in Table 3, while data in each model pair run stems from the same source. This phenomenon is attributable to the different schemes of interpolation applied to point data in these models. The influence of strong topographic gradients is pronounced in PROMET's elevation dependent IDW-approach, such that the temperature values are generally notably below the Hydrotel approach. Deviations in precipitation values are unambiguous, yet within a narrow range. Still, all these differences impose varying model behavior, especially during winter months, when snowfall and snowmelt will take varying courses, and thus adds to the uncertainty in such model chains.

Figure 4 illustrates that the Regional Climate Model is not capable to sufficiently reproduce the current climate, but underestimates the observed precipitation by $400-500 \mathrm{~mm}$. Much of this deviation can certainly be attributed to the coarse spatial resolution of the CRCM $(45 \mathrm{~km})$ and the consequent lack of consideration for the influence of alpine topography and congestion. In addition, heavy convective precipitation, the dominant type of rainfall during the summer months, can not be properly resolved at this spatial scale. The lesser amount of rainfall and the lower temperatures predicted by the CRCM2 Past account for the significant decrease in evapotranspiration rates in both models. CGCM2 Future shows only little change in the course and sum of precipitation, but much higher temperatures cause increased evapotranspiration and dramatically low runoff levels.

The hydrological model performance is evaluated by several flow indicators, such as the mean annual maximum flow (MAMF), mean maximum seasonal flows (MF-DJF and MFJJA) or the annual 7-day and 30-day low flow (aNM7Q and aNM30Q). Table 4 demonstrates the good accordance of flow values for all models when exposed to meteorological observation data and CGCM2 Past. Only the low flow indicators show noteworthy deviation, with PROMET and HSAMI simulating less runoff then Hydrotel, due to its implemented ground water storage concept.

The CGCM Future run reveals a much different picture: The HSAMI model computes runoff far below plausible values. This can be attributed to the sensitive response of the applied evapotranspiration equation to higher temperatures. It is clear, that a model of low physical complexity, which has been calibrated to current climate conditions, is inadequate for application in a climate change context. While PROMET and Hydrotel show at least similar behavior, the amplitude of deviation increases. Comparing floods of different annuality, Fig. 5 depicts a gradual accession of difference between model results using the historic and future climate data set. 
Table 3. Meteorological drivers for winter (DJF) and summer (JJA) periods from different meteorological sources (observation data, ERA40, CRCM2 Past (all 1971-2000) vs. CRCM2 Future (2071-2100)) as interpreted by Hydrotel and PROMET.

\begin{tabular}{lrrrrrrrr}
\hline & \multicolumn{2}{c}{ Observation } & \multicolumn{2}{c}{ ERA } & \multicolumn{2}{c}{ CGCM2 Past } & \multicolumn{2}{r}{ CGCM2 Future } \\
\hline & DJF & JJA & DJF & JJA & DJF & JJA & DJF & JJA \\
Temp [C ]-PROMET $^{-0.94}$ & 14.73 & -5.71 & 13.2 & -4.21 & 13.52 & 1.04 & 18.71 \\
Temp [C ]-Hydrotel $_{\text {Precipitation [mm]-PROMET }}$ & 0.07 & 15.46 & -3.10 & 14.11 & -4.60 & 13.80 & 1.92 & 19.48 \\
Precipitation [mm]-Hydrotel & 214.2 & 510.24 & 244.21 & 284.19 & 162.20 & 249.11 & 177.09 & 222.90 \\
& 187.4 & 496.17 & 184.57 & 301.178 & 163.74 & 266.41 & 180.86 & 234.81 \\
\hline
\end{tabular}

Table 4. Flow indicators $\left[\mathrm{m}^{3} / \mathrm{s}\right]$ for the evaluation of hydrological $(\mathrm{MAMF}=$ mean annual maximum flow, $\mathrm{MF}=$ mean maximum seasonal flow, a $\mathrm{NM}^{*} \mathrm{Q}=$ lowest annual flow for a $*$-day period).

\begin{tabular}{lccc}
\hline & PROMET & HYDROTEL & HSAMI \\
\hline MAMF [observation data] & 98.2 & 93.0 & 93.1 \\
MAMF [CGCM past] & 31.1 & 32.0 & 28.8 \\
MAMF [CGCM future] & 28.3 & 17.7 & 5.6 \\
MF-DJF [observation data] & 59.2 & 84.3 & 91.5 \\
MF-DJF [CGCM past] & 20.3 & 19.6 & 20.0 \\
MF-DJF [CGCM future] & 48.9 & 19.0 & 11.4 \\
MF-JJA [observation data] & 241.8 & 303.0 & 259.8 \\
MF-JJA [CGCM past] & 65.6 & 57.7 & 49.9 \\
MF-JJA [CGCM future] & 36.1 & 24.5 & 6.4 \\
aNM30Q [observation data] & 6.3 & 7.2 & 8.2 \\
aNM30Q [CGCM past] & 1.8 & 5.0 & 2.2 \\
aNM30Q [CGCM future] & 1.1 & 3.9 & 0.5 \\
aNM7Q [observation data] & 5.0 & 6.5 & 7.2 \\
aNM7Q [CGCM past] & 1.4 & 4.8 & 2.0 \\
aNM7Q [CGCM future] & 0.6 & 3.7 & 0.4 \\
\hline
\end{tabular}

The models of less complexity react more sensitive to the changing climate conditions. This may be rated as an indication of the disadvantageous effects of model calibration, resulting in a loss of predictive power for climate change impact assessment.

\section{Summary and conclusions}

It is demonstrated, that the modified climatic boundary conditions cause dramatic changes in hydrologic model response. The lumped model HSAMI shows a tremendous overestimation of evapotranspiration, while PROMET and Hydrotel behave in a comparable range. Still, their significant differences, like spatially explicit patterns of summerly water shortage or spring flood intensity, highlight the necessity to extend and quantify the uncertainty discussion in climate change impact analysis towards the remarkable effect of hydrological model complexity.

The following observations are most noteworthy in this study:

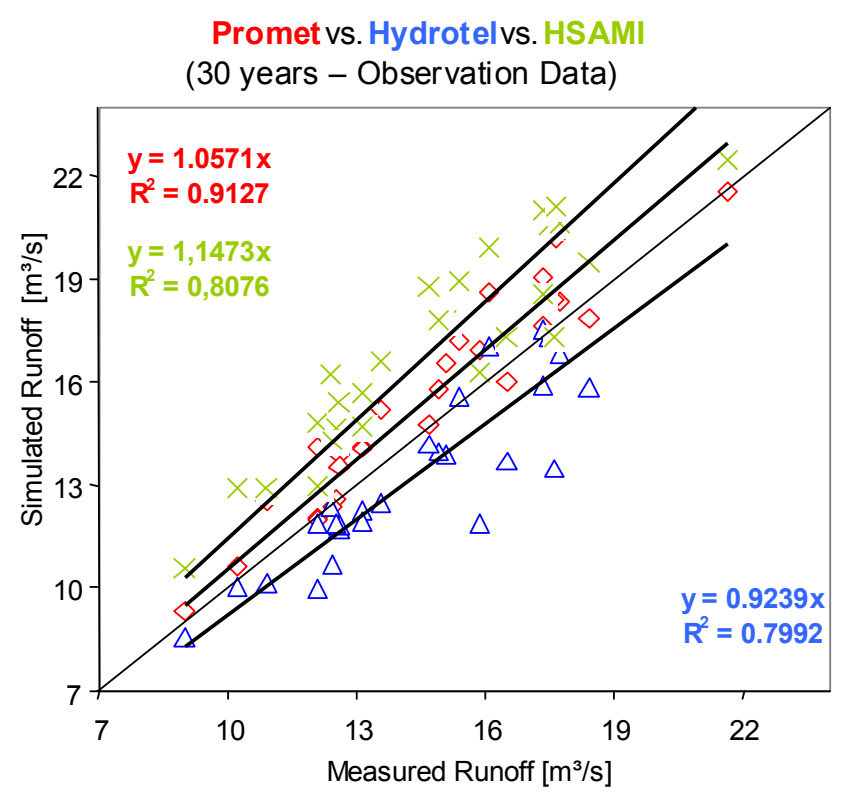

Fig. 3. Measured vs. simulated mean annual runoff (1971-2000), driven by observed climate data.

- The CRCM shows large deficits in predicting the current climate, which is at least partly due to the coarse spatial scale and the consequent lack of consideration for topography and congestion effects. Further research for downscaling climate model output and model integration is required for water resources management on the catchment scale.

- The application of extensive model calibration to current state climate and simple model schemes are inadequate to assess climate change impacts.

- The intercomparison demonstrates that uncertainties induced by hydrological models can be in the same range as the climate scenario inputs.

- The different degree of complexity plays a considerable role when evaluating respective model results - the findings of this study confirm the assumption, that the 


\section{Promet}

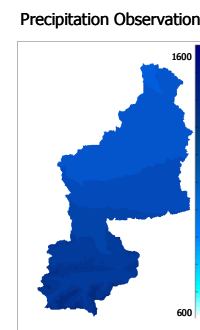

$1289 \mathrm{~mm}$

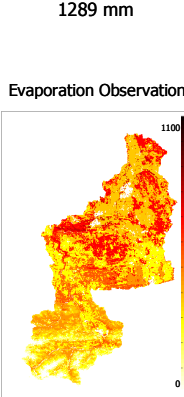

$478 \mathrm{~mm}$

Runoff Observation

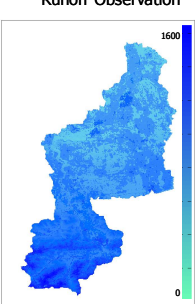

$811 \mathrm{~mm}$

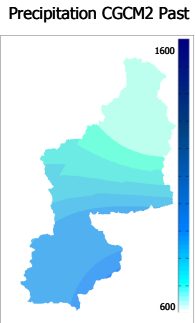

$774 \mathrm{~mm}$
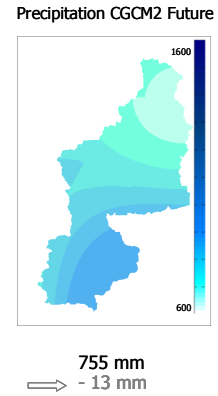

Evaporation CGCM2 Past Evaporation CGCM2 Future

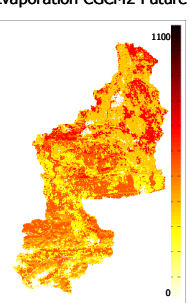

$378 \mathrm{~mm}$
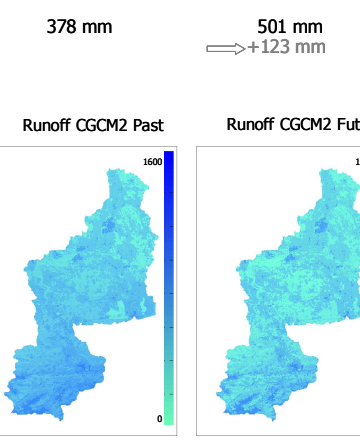

$385 \mathrm{~mm}$

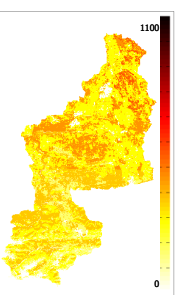
$\Longrightarrow+123 \mathrm{~mm}$

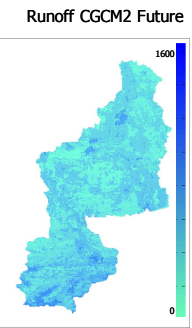

$254 \mathrm{~mm}$
$\Longrightarrow-131 \mathrm{~mm}$
Hydrotel

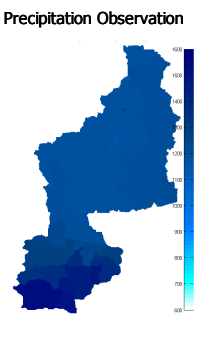

$1244 \mathrm{~mm}$
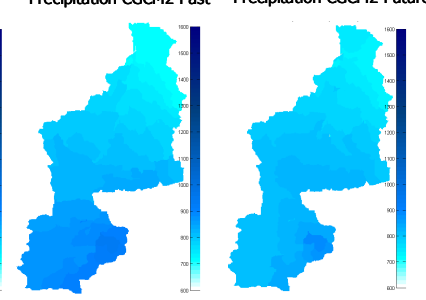

$816 \mathrm{~mm}$ $\Longrightarrow \begin{aligned} 801 \mathrm{~mm} \\ -15 \mathrm{~mm}\end{aligned}$

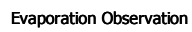

Evaporation CGCM2 Past Evaporation CGCM2 Future
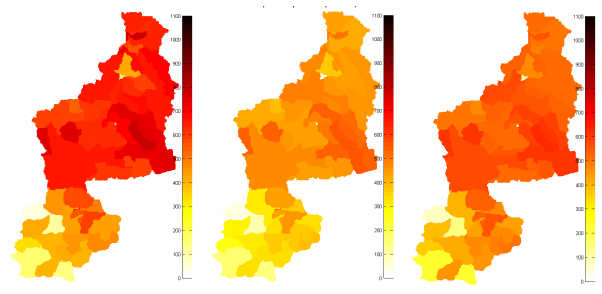

$571 \mathrm{~mm}$

$419 \mathrm{~mm}$ $\begin{aligned} & 501 \mathrm{~mm} \\ \longrightarrow & +82 \mathrm{~mm}\end{aligned}$

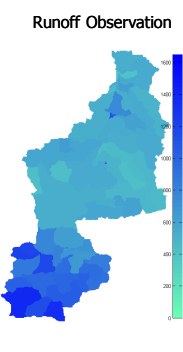

$673 \mathrm{~mm}$

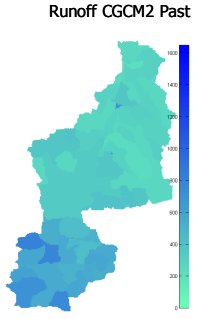

$397 \mathrm{~mm}$

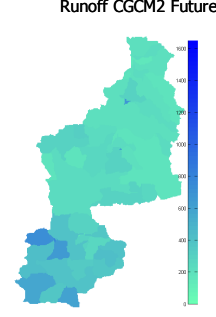

$300 \mathrm{~mm}$

Fig. 4. Comparison of spatially distributed water balance terms (the number beneath the figures indicate the mean annual spatial average and relative deviations) resulting from the PROMET vs. Hydrotel model runs based on meteorological observation data, the CGCM2 Past and the CGCM2 Future (in columns from left to right).

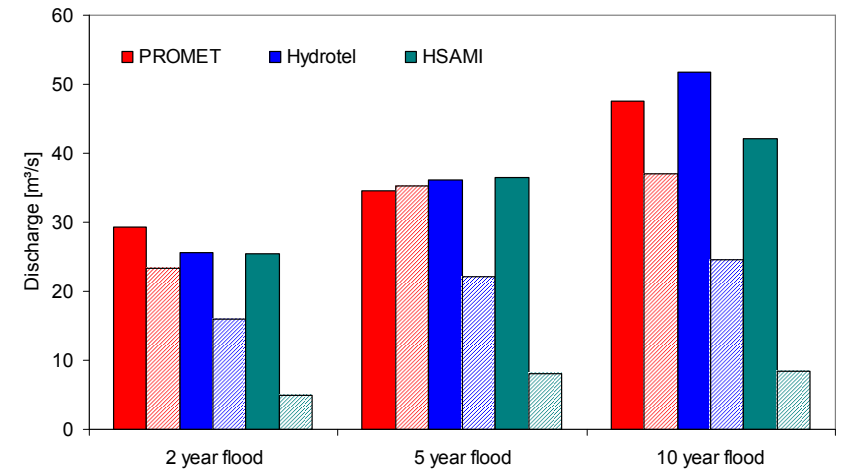

Fig. 5. Comparison of simulated runoff for various flood annualities, as calculated by the different models using climate forcing from CGCM2 Past (solid) and CGCM2 Future (striped). physical basis of process descriptions is indispensable to maintain the predictive power of hydrological models.

The suitable level of complexity and the implications for water managers remain to be discussed in detail for specific application purposes. The consideration of the following recommendations or future research will be useful to make progress towards an effective adaptation of water resources management to climate change:

- Improvement of processes understanding on the impacts of climate change on hydrologic variables.

- Improvement of scaling procedures for the utilisation of regional climate model (RCM) results in regional watersheds management and evaluation and improvement 
of transferability of existing bias correction methods between station measurements and regional climate model outputs for future climate conditions.

- Utilisation and comparison of the existing databases from global and regional climate models (GCM and $\mathrm{RCM}$ ) for the estimation of their respective intrinsic variability and their contribution to the overall uncertainty related to climate change projections.

- Development and application of ensembles of hydrologic models for an improved understanding of the impact of the complexity of process descriptions on simulated hydrological variables and predictive power; evaluation of intrinsic variability and uncertainties in hydrologic modelling.

- Determination of required hydrological model complexity needed for climate change impact studies with specific consideration of the available data for parameterization and of the required accuracy to develop specific adaptation options.

- Development, comparison and evaluation of watershed adaptation options to climate change impacts (to address water quantity and quality challenges, changing land use patterns, dam management, irrigation needs, etc.).

Acknowledgements. The presented study has been conducted in the framework of a Québec-Bavarian pilot study, which focuses on integrative catchment modeling in the context of climate change. Funding from the Québec Ministère du Développement Économique, de l'Innovation et l'Exportation (MDEIE) and the Bayerisches Staatsministerium für Umwelt, Gesundheit und Verbraucherschutz (BStUGV) is gratefully acknowledged. The authors would like to thank the Landesamt für Umwelt for enduring support.

Edited by: B. Schmalz, K. Bieger, and N. Fohrer

Reviewed by: two anonymous referees

\section{References}

Bacchi, B. and Ranzi, R. (Eds.): Hydrological and meteorological aspects of floods in the Alps, Hydrol. Earth Syst. Sci., 7, 783948, 2003,

http://www.hydrol-earth-syst-sci.net/7/783/2003/.

Beven, K. J. and Freer, J.: Equifinality, data assimilation and uncertainty estimation in mechanistic modelling of complex environmental systems using the GLUE methodology, J. Hydrol., 249, 11-29, 2001.

Brugnach, M., Tagg, A. Keil, and F. de Lange, W. J.: Uncertainty Matters: Computer Models at the Science-Policy Interface Marcela Water Resources Management, 21, 1075-1090, 2007.

Duan, Q. Y., Gupta, V. K., and Sorooshian, S.: Shuffled Complex Evolution Approach for Effective and Efficient for Global Minimization, J. Opt. Theor. Appl., 76, 501-521, 1993.
Fortin, V.: Le modèle météo-apport HSAMI: historique, théorie et application. Rapport de recherche, révision 1.5, Institut de recherche d'Hydro-Québec (IREQ), Varennes, France, 68 pp., 2000.

Fortin, J. P., Turcotte, R., Massicotte, S., Moussa, R., Fitzback, J., and Villeneuve, J. P.: Distributed watershed model compatible with remote sensing and GIS data: Description of the model. Journal of Hydrologic Engineering, Am. Soc. Civil Eng., 6(2), 91-99, 2001.

Frigon, A., Caya, D., Slivitzky, M., and Tremblay, D.: Investigation of the hydrological cycle simulated by the Canadian Regional Climate Model over the Quenec/Labrador territory, Climatic Change: Implications for the Hydrological Cycle and for Water Management, in: Advances in Global Change Research,, edited by: Beniston, M., 10. Kluwer Academic Publishers, Dordrecht and Boston, 31-55, 2002.

Garrido, A. and Dinar, A. (Eds.): Managing Water Resources in a Time of Global Change: Mountains, Valleys and Flood Plains, Routledge Press, 272 pp., 2009.

Hagemann, S., Arpe, K., and Bengtsson, L.: No. 24 Validation of the hydrological cycle of ERA-40. ERA-40 Project Report Series, ECMWF, UK, 46 pp., 2005.

IPCC: Climate Change 2007: The Physical Science Basis. Contribution of Working Group I to the Fourth Assessment Report of the Intergovernmental Panel on Climate Change, edited by: Solomon, S., Qin, D., Manning, M., Chen, Z., Marquis, M., Averyt, K. B., Tignor, M., and Miller, H. L., Cambridge University Press, Cambridge, UK, 996 pp., 2007.

Khalili, M., Leconte, R., and Brissette, F.: On the Use of Multi Site Generated Meteorological Input Data for Realistic Hydrological Modeling in the Context of Climate Change Impact Studies, in: EIC Climate Change Technology, 2006 IEEE, 10(12), 1-7, 2006.

Lucarini, V., Calmanti, S., Dell'Aquila, A., Ruti, P.M., Speranza, A.: Intercomparison of the northern hemisphere winter midlatitude atmospheric variability of the IPCC models. In: Climate Dynamics, 28, 829-848, doi:10.1007/s00382-006-0213-x, 2007.

Ludwig, R., Mauser, W., Niemeyer, S., Colgan, A., Stolz, R., Escher-Vetter, H., Kuhn, M., Reichstein, M., Tenhunen, J., Kraus, A., Ludwig, M., Barth, M., and Hennicker, R.: Webbased modelling of energy, water and matter fluxes to support decision making in mesoscale catchments - the integrative perspective of GLOWA-Danube, Phys. Chem. Earth, 28, 621-634, 2003.

Ludwig, R. and Mauser, W.: Modelling the water-balance within a GIS-based SVATmodel framework, Hydrol. Earth Syst. Sci., 4(2), 239-249, 2000.

Ludwig, R., Taschner, S., and Mauser, W.: Modeling floods in the Ammer watershed - Experiences, Limitations and Challenges from a Coupled Meteo-Hydrological Model Approach, Hydrol. Earth Syst. Sci., 7(6), 833-847, 2003.

Mauser, W. and Bach, H.: PROMET - a Physically Based Hydrological Model to Study the Impact of Climate Change on the Water Flows of Medium Sized, Mountain Watersheds, J. Hydrol., accepted, 2009.

Mauser, W. and Ludwig, R.: GLOWA-DANUBE - A research concept to develop integrative techniques, scenarios and strategies regarding global changes of the water cycle, in: Climatic Change: Implications for the Hydrological Cycle and for Water Management, Adv. Global Change Res., edited by: Beniston, M., 
10. Kluwer Academic Publishers, Dordrecht and Boston, 171$188,2002$.

Minville, M., Brissette, F., and Leconte, R.: Uncertainty of the impact of climate change on the hydrology of a northern watershed, J. Hydrol., 358(1-2), 70-83, 2008.

Olsson, J. A. and Anderson, L.: Possibilities and problems with the use of models as a communication tool in water management, Water Resour. Manag., 21, 97-110, 2007.

Plummer, D. A, Caya, D., Frigon, A., Côtè, H., Giguère, M., Paquin, D., Biner, S., Harvey, R., and de Elia, R.: Climate and Climate Change over North America as Simulated by the Canadian RCM, J. Climate, 19, 3112-3132, 2006.

Refsgaard, J. C.: Towards a formal approach to calibration and validation of models using spatial data: Spatial patterns in Catchment Hydrology: Observations and Modelling, edited by: Grayson, R., Blöschl, G., Cambridge, 329-354, 2001.

Schaake, J., Franz, K., Bradley, A., and Buizza, R.: The Hydrologic Ensemble Prediction Experiment (HEPEX), Hydrol. Earth Syst. Sci. Discuss., 3321-3332, 2006.
Sivapalan, M.: Process complexity at hillslope scale, process simplicity at the watershed scale: is there a connection?, Hydrol. Proc., 17, 1037-1041, 2003.

Turcotte, R., Lacombe, P., Dimnik, C., and Villeneuve, J.-P.: Prévision hydrologique distribuée pour la gestion des barrages publics du Québec, Canad. J. Civil Eng., 31(2), 308-320, 2004.

Turcotte, R., Rousseau, A. N., Fortin, J. P., and Villeneuve, J. P. Development of a process-oriented, multiple-objective, hydrological calibration strategy accounting for model structure, edited by: Duan, Q., Sorooshian, S., Gupta, H., Rousseau, A. N., and Turcotte, R., in: Calibration of Watershed Models, American Geophysical Union (AGU), Washington, USA, 153-163, 2003.

Vescovi, L., Cyr, J.-F., Turcotte, R., Ludwig, R., Braun, M., Fortin, L.-G., and Chaumont, D.: A Multi Model Experiment to assess and cope with Climate Change impacts on the Châteauguay watershed in southern Quebec, in: The 3rd UN World Water Development Report: Water in a Changing World, Scientific Side Papers, 1-8, 2009. 